This item was submitted to Loughborough's Research Repository by the author.

Items in Figshare are protected by copyright, with all rights reserved, unless otherwise indicated.

\title{
Christopher Fry's Old Testament drama and replacement theology
}

PLEASE CITE THE PUBLISHED VERSION

http://doi.org/10.3138/md.61.4.0896

PUBLISHER

University of Toronto Press

VERSION

AM (Accepted Manuscript)

PUBLISHER STATEMENT

This paper was accepted for publication in the journal Modern Drama and the definitive published version is available at https://doi.org/10.3138/md.61.4.0896.

\section{LICENCE}

CC BY-NC-ND 4.0

\section{REPOSITORY RECORD}

Brewer, Mary. 2019. “Christopher Fry's Old Testament Drama and Replacement Theology”. figshare. https://hdl.handle.net/2134/26431. 


\section{Staging the Bible in Modern British Drama}

\section{Christopher Fry's Old Testament Drama and Replacement Theology}

Christopher Fry, alongside T.S. Eliot, was at the forefront of the religious drama movement in Britain, which gained prominence in the 1930s with Eliot's The Rock (1934) and Murder in the Cathedral (1935). In the late 1920s, Anglican Church leaders recognised the value of theatre as an evangelising tool, and an arena in which challenges to faith and the Church might be effectively contested. In 1929, the Religious Drama Society (RDS) was founded with the aim of fostering new writing for the stage under the auspices of the Church. The new drama aimed to offer a more sophisticated staging of religious material than offered by traditional mystery or miracle plays in order to compete with popular secular productions. The RDS's aim was set out in its journal, Christian Drama: 'To foster the art of drama as a means of religious expression and to assist the production of plays which explore and interpret the Christian view of life' (Weales 111).

Fry's career as a dramatist has its roots in the RDS. His 1938 play, The Boy with a Cart, a modern take on the medieval miracle play that tells the story of St Cuthman, was written for his local Church's jubilee at the invitation of the vicar; it was later staged at the Bishop's Palace in Chichester. The success of The Boy with a Cart led to a commission by the director of the RDS, E. Martin Browne, to write a pageant play for the Tewkesbury Festival. The Tower (1939), a collaborative undertaking with Browne, launched Fry as one of the RDS's most important writers.

In 1958, the Bishop of Chichester claimed that drama supported by the RDS was transforming the British theatre industry: ' $[\mathrm{m}]$ ore and more plays are being written with spiritual themes and are being performed in the ordinary theatre', because, he suggested, religious drama offered an antidote to the crisis in society - which he defined as the 'spiritual poverty of British culture’ (London Staff 5). Moreover, the Bishop named Fry's plays as among the most significant in terms of 'taking the Christian viewpoint into the popular theatre' (London Staff 5). Theatre critic Harold Hobson made a similar observation, when he observed that whatever the influence of religion upon British life in general might have been at the beginning of the 1950s, Fry's plays suggest that its effect on the stage remained 'considerable' (2).

Although the cure for Britain's 'spiritual poverty' was considered a strictly Christian one, playwrights mined both the Old Testament and New Testament for material to adapt. Plays based on stories, themes, and characters from the books that make up the Hebrew Bible but that approached the source material from a Christian perspective often reveal a struggle against the source texts. This struggle is rooted partly in historic relations between Judaism and Christianity. Dramatic revisions of Old Testament stories must negotiate the same difficult question concerning the relation of the Old Testament to the New Testament that has engaged Christianity since its foundation, and which has contextualized historical tensions between Christians and Jews. Because the roots of Christianity lie in Judaism, Christian typology requires the Old Testament as proving ground for a good deal of material in the New Testament; at the same time, Christian churches have been the originators of replacement theology or supercessionism, a doctrine that contends that many Old Testament values are distinct from and inferior to the Christian principles it claims as having replaced them. 
Anthony Julius' study of the history of anti-Semitism in England discusses the extent to which its foundations lie in the nation's Christian churches. Historically, the Christian establishment sanctified the denigration of Jews and Jewish religious culture. The figure of the theological Jew cast him/her as 'the enemy of the good, the true and beautiful,' and this 'systematized, hostile conception of Judaism and Jews' (563-64) pervaded English public discourse, both religious and secular, from the Middle Ages onward. Notwithstanding, in the modern Church, there were unprejudiced voices. In 1922, Dean William Ralph Inge, a leading Anglican theologian, wrote scathingly of anti-Semitic prejudice, calling attention to Jesus as a Jew: 'it would be inconsistent, after adopting Hebrew texts for our religious services, to be biased against the race that produced them. ...Above all, race consciousness is rather stupid. A rational man [sic] accepts his fellowmen on their merits...' (qtd in Poliakov 217). Similarly, there were also strands of philo-Semitism to be found among the British political establishment, particularly on the part of those who identified with nonconformist religions. Jill Hamilton assesses the relation between a nonconformist upbringing and feelings of solidarity with the Jewish people among politicians during the Great War, citing Lloyd George's expressed preference for the teachings of the Old Testament over the New Testament for example (15).

Yet, as Bryan Cheyette argues, even classic philo-Semitic stances, such as Matthew Arnold's Hebraism, was rooted in a binary between culture and anarchy that spoke to a perceived difference between those Jews who might be assimilated into a civilised culture and those who could not be contained within a civilised state, and thus represented the threat of racialized anarchy (269). Positive attitudes to Jews were underpinned often by less acceptable messianic beliefs, namely the idea that the ingathering of the Jews in Jerusalem and their subsequent conversion was the necessary precursor to the Second Coming of Christ. Arguably, the roots of support among the British political establishment for the Balfour Declaration lay as much, if not more, in imperialist designs on the East that attached to the notion of England as a New Jerusalem as with any concern about Jewish self-determination. Despite glimmers of unbiased feelings toward Jews, a strong undercurrent of anti-Semitism characterized British social discourse throughout the modern period.

Anti-Semitism was especially pervasive in 1930s Britain, but unlike in many continental European states, there was no officially endorsed anti-Semitism or government sponsored persecution of Jews. Anti-Semitism in the inter-war years had an amorphous quality. Malcolm Muggeridge describes how the "hate Hitler generated formed a magnetic field, which reached far, particles of hatred stirred, like iron filings by a magnet, .... Even as far as England the field reached.... Anti-semitism [sic] was in the air, an unmistakable tang" (263-64). This is not to say it lacked real force in society, only that most instances of British anti-Semitism were more nuanced forms of prejudice than the jack-boot variety associated with European fascism.

Todd M. Endelman provides an overview of some of the ways in which anti-Semitism was expressed in British society before and during WWII:

Masonic lodges and golf, tennis, and motor clubs introduced membership bans. Restaurants and hotels advertised that they did not cater to Jews. Garages refused to rent cars to them.... Admission to public schools and the most desirable colleges became more difficult. ... Occupational discrimination became a problem for men and women seeking employment outside traditional Jewish trades..., [especially in medicine and the teaching 
professions]. Newspaper advertisements for secretaries, clerks, and shop assistants specified that Jews would not be hired (199).

Colin Holmes traces how the practical traditions of enmity toward Jews, exacerbated by the anxiety and uncertainty of the inter-war years, can be found in the expression of literary attitudes as well $(213 ; 215)$. Dominant literary discourse helped sustain the Churches 'doctrine of contempt' toward Judaism and Jews, a particular variant of anti-Semitism, sometimes referred to as anti-Judaism in an attempt to distinguish it from forms of prejudice based on race or ethnicity. Holmes argues that the lay theology of writers like G.K.

Chesterton and Eliot expounded a romanticized version of Christendom in which Jews were positioned as cultural antagonists that 'posed a threat to the essential philosophy and organic Christian structures of British society' (211-12). He stresses that such stereotypes of Jews would not have been forwarded if readers were not able to identify with them (219), and the same may be said about the appearance of anti-Semitic or anti-Judaic tropes on the modern stage. Thus, despite a few examples of literary philo-Semitism, such as George Eliot, this discourse has existed together with and usually peripheral to dominant anti-Semitic discourses in British literature.

Cheyette prefers the term 'semitic discourse' to either anti- or philo-Semitism because it eschews the moralising attached to the other terms, and it signifies the ambivalence attached to the figure of 'the Jew' in modern British culture. He writes:

...'the Jew' can be constructed to represent both sides of a political or social or ideological divide. For example, Jews are represented as both the embodiment of liberal progress and as the vestiges of an outdated medievalism,... as the ideal economic man and the degenerate plutocrat par excellence. ... To some extent, this doubleness points to a received Christological discourse which has constructed Jews as both a deicide nation [and] also a nation...on whose redemption the fate of mankind hangs (9).

It is within this 'semitic' cultural milieu that Fry's religious plays were formed and received.

Jonathan Culler contends that "literary works are to be considered not as autonomous entities, 'organic wholes,' but as intertextual constructs: sequences which have meaning in relation to other texts which they take up, cite, parody, refute, or generally transform. A text can be read only in relation to other texts, and it is made possible by the codes which animate the discursive space of a culture" (38). Culler's explanation of intertextuality references how one literary text may connect with another as well as how culture itself is a text, and therefore, the meaning of a play cannot be fully determined apart from its wider discursive context. In the case of Fry's religious drama, one must take into account not only how the plays intersect with their source text, the Bible, but also how they interface with the culture of 'semitic' discourse in Britain. My aim is to determine the extent to which Fry's plays reflect the strain of anti-Jewish bias in British culture that circulated prior to and during their time of production. In addition to The Boy with a Cart, Fry wrote three religious plays: The Firstborn (1946), Thor, with Angels (1948) and A Sleep of Prisoners (1951). In The Firstborn and A Sleep of Prisoners, the playwright explicitly draws upon the Old Testament for either plotline, theme, and/or character. In this chapter, I focus on Fry's staging of Old Testament narratives in The Firstborn and A Sleep of Prisoner's in order to demonstrate how the plays imitate and strengthen the contradictory image of the Jew as bearing the potential for both good and evil that is highlighted by Cheyette. Further, I consider what these plays tell us 
about the relation of Judaism to Christianity in modern Britain and the degree to which Christological discourse continued to rely upon anti-Judaic tropes, even post-Holocaust.

Post-1960s, with the exception of The Lady's not for Burning (1948), Fry's drama has received very little critical attention, apart from Glenda Leeming's 1990 monograph on Fry and Frances Jessup's 2009 re-assessment of Fry's and Eliot's verse drama, neither of which address the question of Semitic discourse in Fry's work. As Cheyette argues in the conclusion to his study of how the 'Jew' is constructed in modern literature, racialized discourse surrounding Jews has been written out of much literary-historical studies of twentieth-century authors, and until account is taken of this history 'it will, in effect, still be continuing' (274). As one of the leading proponents of religious drama during a period in which anti-Semitic codes openly animated the public sphere in Britain, a fresh look at Fry's work with reference to his treatment of Jewish subjects is crucial to understanding the role of modern religious drama in the social processes through which the disparagement and exclusion of religious 'others' takes place.

Fry's 1946 play, Firstborn, re-tells the Old Testament Exodus story. I use the term Old Testament deliberately, for Fry's source was the Protestant Bible. First produced at the Edinburgh Festival in 1948, the play was crafted over a number of years. Begun before the outbreak of WWII in 1938 as a commissioned piece for the RDS's Tewkesbury Festival, but abandoned after the organisers requested instead a pageant play, a draft was not completed until a year after the end of the War. Adopting a pacifist stance, Fry was granted conscientious objector status in WWII, carrying out his national service in the Pioneer Corps. He explains that he continued to rework the play throughout his term of service, whenever he "could find an odd corner in the canteen", even staging an early version of the play with three ladies "borrowed from the amateur society and ... one or two actors in the company' (McDonald).

It is important to note that there are three different versions of Firstborn - the premiere version that was published in 1946 and staged in 1948, a revised 1952 version that appeared in London, and a third version that incorporates changes Fry made for the play's New York production in 1958. According to Jessup, Fry preferred the final and shortest version of the play because he believed that its conciseness made it more dramatically effective. Jessup clarifies one principal difference between the original and final versions to be the greater appeal of Moses; in the final version Moses is a person of greater faith (71). I would argue that the original, despite some verbosity, offers a more coherent dramatic narrative with regard to the play's critique of nationalism, while both the original and final editions afford a problematic revision of the Exodus story by lapsing into anti-Judaic polemic. My reading focuses primarily on Fry’s 1946 script, referring when necessary to substantive changes between the original and final 1958 text.

World War II was a determining influence on Firstborn. In his address to the Society for Theatre Research in 1996, Fry relates his choice of the Exodus story to a concern for the suffering of the Jews during World War II and the failure of people in Allied nations to realise the magnitude of their persecution throughout the 1930s and 40s: "The play I started to write for the Tewkesbury Festival was about the release of the Israelites from Egypt: this was 1938 and our minds were full of the only too little we knew of the Nazis and antiSemitism” (1997, 8). This explains why Fry's Miriam speaks of pogroms and the 'wildfowl quality' of Jewish blood that offers temptation to sadistic 'sportsmen' [Firstborn 24). 
Firstborn transmits a very different memory of Exodus compared to how the text is traditionally received, that is, as a miraculous intervention in human history on the side of the oppressed by the one, true God. For Jews, this transformative moment in their history has been perceived and celebrated as a testament to their specific role in the divine scheme as a moral beacon among nations, an idea denied in Fry's re-inscription. Cecil Wilson's description of the play in a 1952 review for the Daily Mail (4) as a "tragedy of Egypt" signifies how it challenges the authority of the Jewish reading by decentring Moses and the Jews in the narrative. A review in the Johannesburg Star complained that "we see nothing of the Israelites going off - indeed, we see nothing of them at all..." (n.p.), while the Catholic Herald reported more admiringly: Fry "took a time of crisis in civilisation" and succeeded in "universalising its events” (Igoe n.p.).

Anthony Quayle's explanation of the play in the 1958 Coronet Theatre programme (New York) casts the Exodus as an event tinged with shame and remorse for Moses: "He has no sure confidence that the Jews shall come into a Promised Land of their own. The violence appals him, the blame he feels could impale him forever;...” (n.p.). Fry's version of Exodus is neither a story of liberation nor the harbinger of a new religious ethic through the Covenant at Sinai, but rather it poses questions about nationalism, rebellion, and human and divine retribution in a way that uncomfortably aligns or reverses the position of persecutor and persecuted. Norman W. Jones describes how the Bible frequently endorses binaries, while also inverting and questioning them, and for this reason, the Bible has been able to serve as “a rallying cry for the outcast and oppressed" but also as a 'clobber text' to legitimize a host of discriminatory practices (20). Similarly, Firstborn displays an ideological elasticity by virtue of how it attempts to deconstruct the series of binaries that structure the Exodus narrative: birth and death, oppression and resistance, transgression and punishment, and the extra-textual Christian-Jewish binary that informs Fry’s perspective on Exodus.

The Book of Exodus, the second book of the Pentateuch, contains two main narratives: God's liberation of the Israelites from slavery in Egypt and the Covenant between God and Israel at Sinai. Fry re-works only part of the first main narrative (the events recounted in chapters 1-12), ending his play as the Israelites are poised to leave Egypt and venture into the wilderness. He omits reference to Pharaoh's decision to send his army after the Israelites, the miraculous parting of the Reed Sea, God's destruction of the Egyptians who pursue Moses, as well as the people's song of celebration after their safe crossing. A key aim of the original Exodus story is to convey the historical constitution of Israel as a free people and the spiritual constitution of the nation as one set apart from other nations by virtue of accepting the demanding conditions of God's Covenant. However, through omission and revision, Fry's account of the Exodus achieves a very distinct and ironic effect, which calls into question the sanctity of the covenant between God and the Jews. I suggest that the manner in which Fry revises the Exodus narrative invites the audience to approve a brand of religious anti-Semitism.

In the opening scene, Moses' adoptive mother, Anath, explains to Pharaoh's daughter how the baby she rescued from the river 'grew up / Into your tall cousin, / Egyptian / From beard to boots and, ... a soldier of genius' (Firstborn 1946, 4), and how Moses, having 'Recognized his mother's face in the battered body / Of a bricklayer;' 'killed / His Egyptian self in the self of that Egyptian' officer (Firstborn 1946, 6). This account follows the main plot line of the Biblical story, but with a critical difference. Murray Roston concludes that the 'depiction of Moses as a brilliant past general of the Egyptian army ... gives Moses a powerful bargaining point lacking in the original story - a bargaining point which reduces the 
miracle of the Exodus to the level of power politics' (299). Leaving out supernatural elements of the original story, such as when Moses' staff becomes a devouring serpent, and foregrounding Seti's perspective on the plagues as natural occurrences, serves to de-sacralise the events that precede the Israelites leaving Egypt. Roston identifies a trend among twentieth-century dramatists to demythologise Biblical narratives, with the story of Moses most frequently chosen for re-examination stripped of its supernatural elaboration (254), and Fry's play follows this trend.

Fry's title, Firstborn, relates to a number of occurrences in the original Exodus narrative, which are incorporated into the play: Pharaoh's decree 'That all the boys of Jewdom / Should be killed. / for 'Defence of the Realm' (Firstborn, 1946, 3), the defiance of the decree by hiding the infant Moses, and God's destruction of Egypt's firstborn in response to Pharaoh's refusal to free the Israelites. Above all, though, the title of the firstborn in Fry's play references an Egyptian child, Rameses, the firstborn son of Pharaoh. Rameses (absent from the Biblical Exodus) is a well-developed character, who is portrayed in a highly sympathetic manner. His prominence in the drama is one of the main ways in which Fry significantly alters the emphasis and mood of the Biblical Exodus.

Rameses is depicted as the only character free of prejudice, free of the taint of nationalist feeling. In Act one, scene one, he spies two strangers in a crowd: "Jews, but not our Jews": "I looked across and smiled / But got no smiles from them”, he relates (Firstborn 1946, 11). Fry's use of the ethnonym 'Jews' is anachronistic because this term post-dates Exodus, only emerging in the aftermath of the Maccabean revolt (Cohen, ?), but it serves to reinforce how the play attempts to respond Jewish oppression in the modern period. In conversation with I. M. Owen in 1962 about how current events influenced the play's thematic content, Fry relates: "Well, I think we were all very much thinking about the Jewish problem then" (n.p.). This statement, especially the provocative phrase "Jewish problem" further underscores the paradoxical nature of the play’s anti-Judaic bias.

Rameses admires greatly his adopted uncle and seeks to befriend Moses’ birth family. Seti is dismayed by his son's 'free-and-easy good humour, / His good graces for no-matterwhom' (Firstborn 1946, 9). Throughout the play, we see Rameses act out of pure, altruistic motives. He openly challenges Seti: 'You must let the Hebrews go. / Father, you must!' echoing Moses' demand. Most important, he promises to grant the Israelites their freedom if Moses could only be patient: 'There will be difficulties to be got over; / I have a father. But at some future time / When I am Pharaoh - '(Firstborn 1946, 28). Moses, however, will not hear him, interrupting in order to point out that by the time of Rameses' rule he will most likely be dead.

Had Rameses reached adulthood, we are led to believe that he would have ushered in an age of peace between Egyptians and Israelites, without recourse to violence. Whereas Aaron finds hope in Rameses' vision of a more harmonious future between Egyptians and Israelites, perceiving him as 'our man' / The palace key’ (Firstborn1946, 33), Moses dismisses Rameses. The final edition of Firstborn stresses that Moses is aware of Rameses' future potential to benefit humanity, as Fry adds these lines spoken by Moses to Act 1, scene 2: "There will be summers to come / Which need the throne and lotus: a world / Richer for an Egyptian prosperous in wisdom / Which you will govern (Firstborn, 1958, 27). ${ }^{1}$

\footnotetext{
${ }^{1}$ The 1946 edition reads more ambiguously: Moses: "Our roots are the element which gives us purpose / And life. There will be summers to come which need / The lotus. That will be for you." (29)
} 
Consequently, Moses' failure of patience and disregard of Rameses' offer of peace serves to cast his motives and actions as morally dubious. The idea that Moses may be a misguided nationalist aligns him with Pharaoh, whose stubborn refusal to part with his human resources needs no prompting from God in Fry’s story.

The play's critique of nationalism may be considered a response to European power politics in the 1930s and early 1940s, and which underpinned WWII. Peter Lennon notes how Fry abhorred "war and violence", believing that "peace must be preserved without conditions" (B12), and, yet, WWII placed Fry in what the playwright himself described as a "quandary": "what do I do because if ever there was a just war, this was it" (Lennon B12). Fry struggled to find what he might deem a correct ethical response to World War II, which is evidenced by his personal collection of contemporary newspaper clippings in which prominent religious and secular figures, soldiers and those on the home front debated the justice of fighting a war against Germany in particular. A set of related themes come through in the selection of news items that Fry chose to preserve: does God take sides in war? Is war divine punishment? Is Christianity the answer to nationalist aggression? Even in a more emphatically patriotic era, the playwright was not isolated in his questioning of the rightness of the conflict.

There were those who believed, like the Very Reverend Canon G.D. Smith, that 'never has the world seen such a division of Europe into two armed camps, that of God's avowed enemies and that of His friends' (n.p.). Others discounted the notion of divine favouritism in warfare, with one soldier reporting on the views of his "fellow rankers" arguing that they had "too much respect for the ideas or images which we call our God to drag them into the war and its causes (n.p.) The idea that God punished sin through the suffering attendant upon warfare was not an uncommon thesis put forward by both religious and lay persons. The Reverend B. J. Coggle asserted that the war was the result of the "sin of nationalism,” (n.p.) whereas the writer J.B. Priestly identified a sin of omission among the populace; that is, "a lack of religious belief helped to push us all into this black-out" (n.p.). The idea that "true" Christianity was the only answer to the sin of nationalism and warfare is a through-line in most arguments, where Jesus is equated with universalism and peace, while the Nazis, according to Canon Smith, are akin to "the forces of anti-God" that "nailed Christ to the Cross" (n.p.). Of course, Western anti-Semitic discourse has long postulated that the Jews occupy a similar position.

Fry imports elements of these wider cultural debates into Firstborn. According to Stanley M. Wiersma, Rameses is Fry's way of cleaning out the propaganda of World War II from his own heart and life' (54). Fry's "Foreword” to the second edition (reproduced in the third edition), for example, characterizes Rameses as "the innocence, humanity, vigour and worth which stand on the enemy side” (vii). Notwithstanding, as Iain Hamilton's 1952 review in The Spectator shows, some read the play as promoting the idea that Moses clearly had "God on his side" (n.p.). Though at times Fry may imbue his play with a sense of ambivalence about how to respond to oppression and aggression, ultimately, his vision of the Exodus suggests that nationalism, buttressed by false religion, is the factor that, more than anything else, creates a dysfunctional relationship between self and 'other' in society as well as between the individual and God (read the Christian Trinity).

The play implicates the central religious text of Judaism as the source for the process of establishing and valuing the identity of one social group through opposition to other social groups, and by implication, it locates the constituent elements of violence, suffering, and 
death that mark warfare, as well as relations between nation states in the modern period, specifically in Jewishness. One of the clippings that Fry collected about the War repeats this assumption. In an article titled "Can God be on Both Sides," Canon Marriott argues that the Old Testament justifies this point of view by featuring a "Jehova whose main task was to go out with the armies of Israel and ensure their victory," whereas Jesus "put an end to all tribal and national ideas of God" (n.p.). This perspective repeats the kind of Christian antagonism toward Judaism and concomitantly Jews that John K. Roth stresses "was a necessary precondition” for the horrors of WWII (120), a fact about which the play seems disturbingly obtuse.

That Moses may have profane motives in battling Pharaoh is given credence by the way in which Fry rewrites his response to God's commission. In the Bible, Moses appears on several occasions unsure of himself as God's spokesperson. In Exodus 3:11, he asks "Who am I, that I should go unto Pharaoh, and that I should bring forth the children of Israel out of Egypt?” (Exodus, 3:11), while in 4:10, he pleads a lack of eloquence to do so. Conversely, Fry's character is never at a loss for words to forward his cause, appearing at times as an emblematic insurgent; as Aaron observes, he goes from tent to tent 'manipulat[ing] / Man upon man into consciousness' (Firstborn 1946, 76). Fry's characterisation of Moses echoes Nietzsche's conception of the superman, a not unusual comparison in modern drama; according to Roston, on the twentieth-century British stage, often Moses was depicted as 'dragging by the sheer force of his own personality a reluctant illiterate rabble on to victory.... Frequently ruthless, and unshakeable in his certainty, he emerges less as a servant of destiny than as its creator...' (254)

Unsurprisingly, then, the extent of Moses' faith in God appears ambiguous, particularly in the first edition of Firstborn. Jessup recognises how Moses seems to 'firmly believe he is using God, and not the other way round, until the dénouement' (23). In Act One, scene three, Fry endows Moses with speech that suggests near godlike confidence. While defending his actions to Anath, Moses asks: “Am I given the power / To do what I am? (Firstborn 1946, 45), which, at this point in the narrative, may be read in several ways. Failing her response, the question could be simply rhetorical. Or, given that the scene ends with a second question: "What says the infinite eavesdropper?", followed by the stage direction: "From horizon to horizon the sky is beaten into thunder" (Firstborn 1946 46), Moses could be appealing God. Alternatively, the manner in which Fry employs the interrogative mode allows for the possibility that Moses is being self-reflective, and because the phraseology - 'Am I', 'what I am' -prompts us to recall God's self-definition in Exodus 3:14: 'I AM THAT I AM,' the lines could be asserting, perhaps unconsciously, Moses' singular power, including a less than reverent call for the 'eavesdropper' in the background to confirm his authority.

Until the point at which Moses realises that freedom for the Israelites hinges upon Rameses' destruction, he remains unwavering in his belief in the correctness of the campaign he leads against the Egyptians, including the slaughter of all firstborn. On the surface, the play affords a reading of the final plague as a kind of poetic justice, in light of Pharaoh's earlier warrant to destroy the Jewish children. This idea of retributive justice is reiterated in Act 1, scene 3, when Moses uses the dead body of an Israelite boy as a symbol of 400 years of Egyptian persecution. Laying the body at Seti's feet, Moses says: "It was done of you. You'll not / Escape from yourself through the narrow gates between” (Firstborn 1946, 42). 
Fry's concern to extend the Exodus into a protest against human suffering and oppression more generally leads him to present Moses' response to the suffering of the Egyptians as inhumane, and as unjustifiable as Pharaoh's response to the Jews' suffering, even in the face of continued Egyptian oppression. Most contemporary critics failed to identify the connection between Moses and Pharaoh. Derek Stanford, for instance, considers Seti not evil in himself, 'but in securing the greatness of Egypt he is led to employ evil methods' (1952, 122). One critic describes Seti in modern terms as a "totalitarian tyrant," one whose "obsession with the dynasty has overlaid his sense of the rights of individuals" (D.S., n.p.), while another critic sees him as "antedating Hitler by 3000 years" (Playfellow, n.p.). In the play, however, by welcoming the plaques in support of his nationalist campaign, Moses is held to guilty of the same kind of sin against humankind and God as Pharaoh. Fry's play goes beyond simply championing a pacifist stance. Firstborn contains an anti-social critique, in the sense of being opposed to the principles on which power and political practice is organised in society, and which it incorrectly associates with the Old Testament or Jewish religious values.

I would not suggest that Fry imagines the concern with realpolitik in the plot of the Biblical Exodus. Walter Brueggemann, for instance, considers the Exodus tale paradigmatic of Israel's political theology: 'The self-presentation of Israel in song and story' ... 'is inescapably a political theology in which $\mathrm{YHWH}$, the god of Israel, is intensely engaged with questions of power and with policies and practices...' (9). However, Brueggemann goes on to demonstrate how God in the Biblical Exodus is positioned as an anti-Pharaoh type. Pharaoh is absolutist, arrogant and brutal, and he makes laws that are rooted in fear of loss loss of material wealth and power. In contrast, God, as a political agent, favours a Covenantal mode of public power in which goods are distributed fairly, individual initiative is indispensable, and legitimate protest is encouraged (?).

Because Fry's concerns are eschatological and not with the material realm, however, he ends up repeating the stereotypical conception of the Old Testament God as a war-like figure who will not hear the voice of peace. Firstborn assumes a cynical stance regarding the possibility of social redemption. The end of the revised version especially, in which the dead body of Rameses is framed in light, signals the idea that people should be concerned most about the world to come after death, and, as I discuss in more depth later, through linking Rameses to Jesus, the play expounds the notion that redemption is possible only through faith in Christian tenets.

In the original version of The Firstborn, Moses comes to feel keenly that he erred in his earlier judgments. At the end of the first edition, the scene resembles a Jacobean tragedy the dead body of a child lies centre stage, and in the off-stage world, the spectator knows that the streets and villages of Egypt are littered with corpses. In re-writing the play, Fry achieves a slightly different effect by changing the order of the final lines and the timing of Moses' exit. The first edition ends with dialogue between Teusret and Seti, remarking on the tragic irony of Rameses' bride having arrived at the moment of his death. In the final version, the last words belong to Moses, who tells Anath: 'We must each find our separate meaning / In the persuasion of our days / Before we meet in the meaning of the world. / Until that time.' (Firstborn 1958, 87). In addition, Fry lightens the tone of the scene by adding the stage direction: 'He goes. The early light reaches Rameses.' (Firstborn 1958, 87). The hopeful quality of the revised ending, following on from Moses' impassioned pleas for the life of Rameses and his perplexity concerning “... why the necessity of God / Should feed on grief” 
(Firstborn ${ }^{2} 1958,86$ ), rings false. It is out of keeping with the tenor of Moses' character overall in both versions of the play. Anath's final words to Moses, warning him that he 'will have nothing now except the wilderness' (Firstborn 1958, 86), seem a more realistic appraisal of Moses' state of mind and relation to God after Rameses’ death.

Moses does not appear as the great prophet of the Bible in Firstborn, but rather he remains a morally flawed individual, who is unbending and at times driven by ego. In themselves, these facets of the play do not replicate the essential structures of anti-Judaic discourse. Yet, other revisions to the Exodus narrative do conform to anti-Judaic biases. To understand the moral logic of Firstborn, it is necessary to consider more broadly the theology that informs Fry's religious drama. Wiersma articulates the playwright's doctrine of atonement and resurrection, which he bases on numerous interviews with Fry as well as personal correspondence:

All individuals and communities begin with a childish passive aggression, and some stay there. Some progress through an aggressive phase on behalf of a cause, and some progress even further to an aggressive phase on behalf of God. The final phase is enduring aggression, and when no arrested development impairs, we survive death from aggression just as Jesus Christ did (270).

Firstborn positions the religion of the Israelites, embodied in the figure of Moses, as falling between two aggressive phases - violence on behalf of a cause and on behalf of God. Hence, Fry's depiction of the Exodus reinforces supercessionist thinking, whereby a dichotomy is drawn between Old Testament Jewish religion, rendered as more akin to primitive or pagan belief and practice, and an ostensibly more enlightened and non-violent Christian faith. Fry's commitment to replacement theology is evident not only in his redrawn Moses, but also in the way he writes the Jewish God.

If Fry's Moses is portrayed as less than the heroic figure usually associated with the Exodus, Moses' God appears as an even less attractive entity. In the play, the series of plagues render the events of the Exodus as a violent religious crusade in which God is implicated even more than Moses. Leeming argues that Fry harnesses the story of Exodus as a vehicle to portray the consequences of "man's inhumanity to man [sic], and the place of God in permitting it” (23). She suggests that the plagues gradually lead Moses to realise his powerlessness in the face of a vengeful and destructive God (24). This reading accords with how Fry makes the Exodus a personal tragedy for Moses, who mourns 'having followed a light into a blindness' (Firstborn 1946, 98). If, following Leeming, we read Moses as a pawn in a holy war, the God of the Jews becomes the instigator of the unnecessary violence and death that saturates the world of the play.

Firstborn portrays Old Testament religion as driven by nationalist aggression compared to the New Testament religion of universal 'brotherhood' and peace. Thus, the play falls into what Diarmaid MacCulloch calls the "casual unthinking Anti-Semitism, which characterized British society until the late twentieth century," and which he locates in the roots of Chalcedonian Christianity. MacCulloch finds casual anti-Semitism to have been a pernicious force in the modern period, because it allowed Christians to be co-opted into dehumanizing Jews. Europeans 'absorbed eighteen centuries of Christian negative

\footnotetext{
${ }^{2}$ These lines also appear in the original edition $(1946,100)$.
} 
stereotypes of Judaism - not to mention the tensions visible in the text of the New Testament, which had prompted the urge to create those stereotypes, up to the most mendacious and marginalizing such as the 'blood libel' (MacCulloch 948). By virtue of replicating a Christian/Jewish binary in which Christianity assumes a role of moral dominance over Judaism, Firstborn serves as a vehicle for the continued circulation of such negative stereotypes of Jews, as well as an indicator of continuing tensions between Christianity and Judaism in post-Holocaust Britain.

Even more disturbing are those instances where Fry's script skirts close to racial essentialist thinking about Jews. Conceptually, Fry imprisons the Jewish-identified Moses within an ontology of sameness, what the critic for the Manchester Guardian calls his "racial loyalty" ("Library Theatre" 7). The idea that Jews are a distinct race, and act based on race, is suggested by references to the Jews' "dark blood," which is a sign that separates Israelites from Egyptians in the play, and not just a reference to the blood of the lamb spread over the doorposts. In Act three, scene one, Moses refers to “...we who have the darkness / Here in our blood” (Firstborn 1946, 80), ${ }^{3}$ while Anath speaks of Moses' blood being tainted: "I would rather infect him [Rameses] with something less dubious / Than the blood of Moses" (Firstborn 1946, 38). Here, Anath locates Moses' actions against the state in his very being as opposed to his politics.

Moses' hybrid status as both Hebrew by birth and Egyptian by adoption requires careful negotiation if he is to realise his political ambitions, and his emotional relationship with Rameses further complicates things. Against the backdrop of having to unify the Israelite slaves into an effective nationalist movement, Moses feels compelled to construct ontological borders as tools of inclusion/exclusion. The most significant example of Moses' ideological position occurs in Act 1, scene 3, during which Rameses points out that negotiations between Egypt and the emerging Israelite nation could have gone "Some other way than this. Is only Israel / Present to you as once it was only Egypt?” Until the point of Rameses' death, Moses' actions in the play require an affirmative answer. (Firstborn 1946, 44).

Borders and border crossings are important symbols because of the way they relate to the divide between self and 'other' in Firstborn. After killing the Egyptian officer, Moses literal border crossing into Midian reinforces his rejection of his Egyptian selfhood and concomitant embrace of his Israelite identity, and too, it signals his tendency to imagine ideological borders to be fixed like geographical ones. However, the play's most poignant account of border crossing involves Moses' failed attempt to create a protective circle of lifeforce around Rameses as the angel of death passes over Egypt.

Moses. Has none of us the life

To keep him living? Pain of man, iron

Of nature without record, sacrifice, faith

Storm-riding souls and rearing of spirit,

Are we the way through, letting in destruction? (Firstborn, 1946, 97). ${ }^{4}$

\footnotetext{
${ }^{3}$ Fry adds in the third edition this line was spoken by Anath: 'I would rather infect him with something less duious / Than the blood of Moses'.

${ }^{4}$ The final edition omits the line: 'Are we the way through, letting in destruction', and thus, lessens Moses' sense of personal quilt.
} 
With Rameses' death, Moses realises that he has served to open a portal to the destruction of innocence. Addressing God directly, he laments how "good has turned on itself and become / Its own enemy. Have we to say that truth is only / Punishment?" (Firstborn 1946, 95). Yet, Moses' response to Rameses' death ameliorates only slightly the severity of his character because of its particularity. He cannot see the suffering of the majority of Egyptians, viewing them either as abstractions or failing to even distinguish between their deaths and the death of 'cattle' and 'flocks' (Firstborn 1946, 80). Moses can see only the suffering of the one who resembles an earlier version of himself. Reflecting on his play, Fry stated that he had aimed to show that "to Moses the boy represented Moses' own boyhood when he was Prince of Egypt...”” (1952, 31).

Fry contrasts Moses’ particularism with Rameses’ universalism, for Rameses, unlike Moses, can identify with the 'other'. Early on, Rameses comments that upon Moses departure, “something of us, I think, went with him” (Firstborn 1946, 19). Unlike Moses, who seems oblivious to Egyptian suffering, Rameses empathises with the suffering of the Israelites. He is horrified to witness "...Shendi, the son of Miriam, a Jew / Beating a Jew” (Firstborn 1946, 67). He goes even further, claiming that "I raised that arm. / I struck that Jew" by virtue of having given Shendi a role of authority over his fellow Israelites (Firstborn 1946, 68).

Through a series of empirical encounters in which he expresses a sense of obligation to another, Rameses may be read as transcending the particular - his Egyptian nationality and expected loyalties, whereas Fry denies any quality of transcendence in the Israelite character. For most of the play, Moses, who claims to be carrying out God's will in his quest to free the Israelites, is shown by Fry to be moving further away from an ethical conception of the divine. In contrast, the play invests Rameses with an ethical position that aligns him with Jesus, as represented in Matthew 12. In Matthew's Gospel, Jesus gives a set of ethical injunctions that are intended to transcend or 'correct' Jewish law by raising compassion above it. Similarly, Rameses' desire to liberate the Israelites goes above his father's national law that stipulates their slave status, in order to announce a new dispensation of equality and mercy.

Rameses' death is represented as a double tragedy - a tragic loss for the Egyptians and the Jews, for at the end of the play, it is unclear what awaits Moses and the Jews postemancipation other than a state of sad bewilderment and guilt as they wander through the desert. The tenor of the play's end traverses the extra-textual Christian stereotype of the 'wandering Jew' - a trope based on the idea that the Jews as a people are cursed by God. In so far as Rameses symbolises innocence, love of humanity, and mercy, Fry's theological worldview cannot sanction something good arising out of his death. In terms of how the play intersects with wider Semitic discourse, Moses failure to recognise in time Rameses true worth is made to prefigure the Jews' failure to recognise another, later figure of peace Christ. Consequently, Rameses' connection to Christ serves to recall the Christian charge of the Jews as a deicide nation.

Although Firstborn does not openly attack Judaism or Jews, its revision of the Exodus text delivers an adverse representation of both. Fry's loose adaptation of Exodus foregrounds the suffering of Egypt, with the effect of displacing the Jews in one of their foundational religious narratives. The play disregards the complexity of the Biblical story - how its doctrine blends elements of what might be termed the religiously impure and pure; in other words, Fry chooses for adaptation those elements of the text that modern spectators would 
likely find distasteful and uses them to define Moses, and by extension the Jews and their religion.

Moses appears as a coarsened personality in comparison to Rameses, the latter of whom is portrayed as akin to a tragic hero; he is anachronistically invested with a modern perspective on slavery and an enlightened vision of self and 'other'. Rameses' highly emotive death serves to push the issue of the Jews' enslavement further into the background, and contributes toward the representation of their drive to freedom and self-determination as morally dubious. There is no reason to believe that Fry was not genuinely distressed by the loss of Jewish life in WWII. At the same time, the playwright constructs the figure of the 'Jew' in relation to a supercessionist ideology, which runs throughout The Firstborn, and this current creates a sad irony, because, by repeating Christian forms of animosity toward Judaism and Jews, the play risks amplifying the kind of prejudice that gave to Jewish suffering in the first place.

\section{Works Cited}

Anon. Johannesburg Star. “Christopher Fry Makes a Bore out of Moses.” 11 February, 1952.

Anon. “Library Theatre: ‘The Firstborn’”. Manchester Guardian. Dec. 3, 1952, p. 7.

Anon. "God and the War: The Faith of a Private Solider.” News Chronicle. Tuesday, February 4, 1941. THM/319/7/38. V\&A Theatre and Performance Collection. London. 11 Sept. 2016.

Aurelius Augustine. C. 417. The City of God, Volume II. Ed. Rev. Marcus Dodds. www.gutenberg.org/files/45305/45305-h/45305-h.htm [Accessed 4 April 2016]

The Bible: Authorized King James Version. Oxford: Oxford UP, 2008.

Brueggemann, Walter. 'Scripture: Old Testament.' The Blackwell Companion to Political Theology. Ed. Peter Scott and William T. Cavanaugh. Oxford: Blackwell, 2007, 720.

Cheyette, Bryan. Constructions of 'The Jew' in English Literature and Society: Racial Representations, 1875-1945. Cambridge: Cambridge University Press, 1993.

Coggle, Rev. B. J. "View of a Pacifist.” News Chronicle. 31 Jan. 1941. War Folder. THM/319/7/39. V\&A Theatre and Performance Collection. London. 15 July 2016.

Cohen, Shaye J.D. The Beginnings of Jewishness: Boundaries, Varieties, Uncertainties. Berkeley: University of California Press, 1999.

Cookman, Anthony. “At the Theatre: Mr. Christopher Fry’s Festival Play.” The Tatler and Bystander. 6 June 1951. 516. THM/319/7/14 (2 of 2).

Culler, Jonathan. The Pursuit of Signs: Semiotics, Literature, Deconstruction (Ithaca, New York: Cornell Univ. Press, 1981).

D.S. “The Firstborn.” Friend. 8 February 
Endelman, Todd M. The Jews of Britain 1656 to 2000. Berkeley: University of California Press, 2002.

Fry, Christopher. [1951] A Sleep of Prisoners. London: Oxford UP, 1954.

_. The Firstborn. London: Oxford University Press, 1946.

_ “Foreword.” The Firstborn. $3^{\text {rd }}$ ed. London: Oxford University Press, 1958. . The Firstborn. $3^{\text {rd }}$ ed. London: Oxford University Press, 1958.

. An experience of Critics. London Perpetua, 1952.

Oct $14, \overline{\text { p. } 107 .}$.

. “Drama in a House of Worship: ‘Dream’ Problems.” New York Times. 1951

. "Introduction.” The Winter Tree: Good Friday Anthology. 1960. Typescript. Folder 2: Prologues. THM/319/2/2. V\&A Theatre and Performance Collection. London. 11 Sept. 2016.

. "The Early Days: The text of the Annual Address given to the Society for Theatre Research by Christopher Fry on 14 May 1996”. London: Society for Theatre Research, 1997. Collection. London. 11 Sept. 2016.

Handwritten note. THM/319/2/2. Folder 11. V\&A Theatre and Performance . "Faith and the Anti-Hero.” THM/319/2/2. Folder 11. V\&A Theatre and Performance Collection. London. 11 Sept. 2016.

. "Christianity and the Theatre.” THM/ 319/2/2 Folder 1: Articles/Reviews. V\&A Theatre and Performance Collection. London. 11 Sept. 2016.

Hamilton, Iain. “The Firstborn.” The Spectator. 8 February. SEE

Hamilton, Jill. Gods, Guns and Israel: Britain, the Jews and the First World War. Stroud, Gloucestershire, The History Press, 2009.

Hobson, Harold. ‘Sartre and Fry’. The Sunday Times July 29 1951, p. 2. . Review. Christian Science Monitor. 9 Weds. 1952, p. 9. THM/319/7/14.

Folder 2. V\&A Theatre and Performance Collection. London. 10 Sept. 2016. 1979.

Holmes, Colin. Anti-Semitism in British Society: 1876-1939. London: Edward Arnold,

Igoe, W. J. 'The Firstborn (The Winter Garden Theatre).” Catholic Herald. 8 Feb. 1952. Folder 7. THM/319/7/8. 
Isaac, Jules. The Teaching of Contempt: Christian Roots of Anti-Semitism. New York: Holt, Rinehart and Winston, 1964. TRANS.

Jessup, Frances. Christopher Fry: A Dramatic Reassessment of the Fry/Eliot Era of British Verse Drama. Palo Alto, CA: Academia Press, 2009.

Jones, Norman W. The Bible and Literature. London: Routledge, 2016.

Kerr, Walter F. "Ecclesiastical First Night.” New York Herald Tribune. 17 October 1951. THM/319/2/2 (16 of 17). V\&A Theatre and Performance Collection. London. 9 Sept. 2016.

Leeming, Glenda. Christopher Fry. Boston: Twayne Publishers, 1990.

Lennon, Peter. “The Gent’s Not For Turning.” The Guardian. Dec. 8 1997, p. B12. Proquest Historical Newspapers.

MacCulloch, Diarmaid. A History of Christianity: The First Three Thousand Years. London: Penguin, 2010.

Marriott, Canon. “Can God be on Both Sides?” News Chronicle. 27 Jan. 1941. War Folder. THM/319/7/39. V\&A Theatre and Performance Collection. London. 9 Sept. 2016.

McDonald, Robert. Interview with Christopher Fry. 31 March 1979. Folder 16. THM/319/2/2.

Muggeridge, Malcolm. The Thirties, 1930-1940 in Great Britain. London: Collins, 1967.

Owen, I.M. Fry: The Firstborn: Comments made by Christopher Fry in a conversation with I.M. Owen. 20 June 1962. Folder 7. THM/319/7/8.

Poliakov, Léon. The History of Anti-Semitism: Volume IV Suicidal Europe, 18701933. Oxford: Oxford University Press, 1985.

Playfellow. "The Paint and the Powder.” Truth. 8 February.

Priestley, J. B. “God and the War: Introduction.” News Chronicle. 1941. War Folder. THM/319/7/39. V\&A Theatre and Performance Collection. London. 8 Sept. 2016.

Quayle, Anthony. 'The Story of the Play.' The Firstborn: Programme. Coronet Theatre, New York, 30 April. 1958. Folder 5. THM/319/5/6. V\&A Theatre and Performance Collection. London. 15 July 2016.

Roth, John K. Ethics During and After the Holocaust: In the Shadow of Birkenau. Houndmills, Basingstoke: Palgrave Macmillan, 2005.

R.K.P. “Fry Sees his Festival play launched in St. Peter's Church, Bournemouth.” Bournemouth Daily Echo. 12 May. THM/319/7/14 (2 of 2). V\&A Theatre and Performance Collection. London. 15 July 2016. 
Robinson, Kenneth J. "From Shakespeare to Eliot and Fry." Church of England Newspaper. 25 May. THM/319/7/14 (2 of 2). V\&A Theatre and Performance Collection. London. 15 July 2016.

Smith, The Very Reverend Canon C. G. "Is this War a Punishment for Our Sins?" War Folder. THM/319/7/39. V\&A Theatre and Performance Collection. London. 15 July 2016.

Stanford, Derek. Christopher Fry. London: Longmans, Green \& Co., 1962.

Christopher Fry: An Appreciation. London: Peter Neville Ltd., 1952.

Weales, Gerald. Religion in Modern English Drama. Philadelphia: University of Pennsylvania Press, 1961.

Wiersma, Stanley M. More Than The Ear Discovers: God in the Plays of Christopher Fry. Chicago: Loyola UP, 1983.

Wilson, Cecil. 'Firstborn Without Fry Frills'. Daily Mail. January 30, 1952; pg. 4; Issue 17375.

. “Here’s a Bitter Sermon.” Daily Mail. May 16, 1951, p. 4. JUDAS 